Research Article:

\title{
Effect of Fermented Camel Milk on Obesity Measures and Blood Pressure of Adolescents With Metabolic Syndrome
}

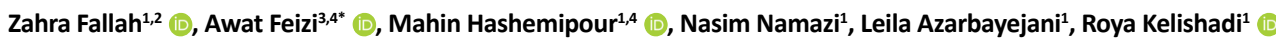

1. Department of Pediatrics, School of Medicine, Child Growth and Development Research Center, Research Institute for Primordial Prevention of NonCommunicable Disease, Isfahan University of Medical Sciences, Isfahan, Iran.

2. Students Research Committee, Isfahan University of Medical Sciences, Isfahan, Iran.

3. Department of Biostatistics and Epidemiology, School of Health, Isfahan University of Medical Sciences, Isfahan, Iran.

4. Isfahan Endocrine and Metabolism Research Center, Isfahan University of Medical Sciences, Isfahan, Iran.

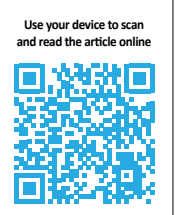

CFtation Fallah Z, Feizi A, Hashemipour M, Namazi N, Azarbayejani L, Kelishadi R. Effect of Fermented Camel Milk on Obesity Measures and Blood Pressure of Adolescents With Metabolic Syndrome. Journal of Pediatrics Review. 2019; 7(3):181-189. http:// dx.doi.org/10.32598/jpr.7.3.181

doi http://dx.doi.org/10.32598/jpr.7.3.181

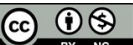

Article info:

Received: 27 January 2018

First Revision: 12 June 2018

Accepted: 30 June 2018

Published: 01 July 2019
Keywords:

Metabolic Syndrome, Fermented milk products, Camelus, Adolescents, Crossover studies, Chronic disease

\begin{abstract}
A B STRACT
Background: Metabolic Syndrome (MetS) predisposes the human body to a variety of chronic diseases.

Objectives: This study, for the first time, aimed to assess the effects of Fermented Camel Milk (FCM), a functional dairy food, on the obesity measures and blood pressure of adolescents with MetS.

Methods: This was a crossover, randomized, double-blind trial. We enrolled overweight or obese adolescents, aged 11-18 years, meeting the diagnostic criteria for MetS. We randomly assigned the study participants to receive FCM $250 \mathrm{~mL}$ per day for 8 weeks, followed by a 4-week washout, then, consuming Diluted Cow Yogurt (DCY) $250 \mathrm{~mL}$ per day for 8 weeks, or the reverse sequence. General and abdominal obesity measures consisting of weight, Body Mass Index (BMI), BMI z-score, Waist Circumference (WC), Hip Circumference (HC), waist to height ratio and Systolic and Diastolic Blood Pressure (SBP, DBP) were measured before and after each of the 4 periods. A three-day food record and physical activity questionnaire were completed before each period. Statistical analyses were performed using Minitab and SPSS considering the significance level of 0.05 .
\end{abstract}

Results: Twenty-four participants with the Mean $\pm S D$ age of $13.77 \pm 1.87$ years (age range: 10.45 16.25 years) ( $58 \%$ girls) completed the study. It resulted in nonsignificant mean changes (increase or decrease) in weight of $-0.67 \mathrm{~kg}(95 \% \mathrm{Cl}:-1.97 ; 0.61 ; \mathrm{P}=0.28), \mathrm{BMI}\left(-0.10 \mathrm{~kg} / \mathrm{m}^{2}, 95 \% \mathrm{Cl}:-0.65\right.$; $0.45 ; \mathrm{P}=0.70)$, BMI $\mathrm{z}$-score of -0.06 ( $95 \% \mathrm{Cl}:-0.33 ; 0.19 ; \mathrm{P}=0.59)$, WC of $-1.10 \mathrm{~cm}(95 \% \mathrm{Cl}:-3.22 ; 1.01$; $\mathrm{P}=0.29)$, and $\mathrm{HC}$ of $-0.12 \mathrm{~cm}(95 \% \mathrm{Cl}:-2.04 ; 1.79 ; \mathrm{P}=0.89)$ by $\mathrm{FCM}$ consumption in comparison to $\mathrm{DCY}$. The study also resulted in non-significant mean reduction in DBP of $-4.45 \mathrm{~mm} \mathrm{Hg}(95 \% \mathrm{Cl}:-10.04$; 1.12; $\mathrm{P}=0.11$ ).

Conclusions: According to some positive impacts of FCM on obesity measures and blood pressure, we suggest conducting further studies to validate the clinical impacts of fermented camel milk.

* Corresponding Author:

Awat Feizi, PhD.

Address: Department of Biostatistics and Epidemiology, School of Health, Isfahan University of Medical Sciences, Isfahan, Iran.

Tel: +98 (31) 37923250

E-mail: awat feiz@hlth.mui.ac.ir 


\section{Introduction}

schemic heart disease and cerebrovascular disease have been the leading causes of global disability-adjusted life year in recent years (1). Concurrently, the metabolic risk factors, such as high Body Mass Index (BMI) and fasting plasma glucose significantly increased (2). Meanwhile, youth health has been largely neglected globally (3). Metabolic Syndrome (MetS), the aggregation of major cardiometabolic risk factors associated with excess weight (4), is prevalent in the pediatric population, predisposing them to a variety of chronic diseases. Lifestyle change, including diet, is part of the treatment plan in this regard (5). Diets with higher healthy eating indices have a protective effect on the occurrence of pediatric MetS (6).

Camel milk has been used for controlling Diabetes Mellitus (DM) by traditional medicine. Some favorable effects of camel milk are reported in a number of animal and human diabetic populations (7-13) as follows: terminating biochemical and immunohistochemical alterations after DM induction in albino rats (7), reducing daily insulin doses in type $1 \mathrm{DM}$ patients (8), reducing glycemic indices in type 2 DM patients (9), modifying hyperglycaemia and oxidative damage in animal studies (10), positive effects on incretin hormones, insulin resistance, and inflammatory cytokines (11), and promoting immune functions (12) in experimental DM. Furthermore, a systematic review has documented the beneficial effects of camel milk on DM (13).

Some effects of camel milk might be attributed to its probable insulin content and its effect on insulin-related metabolic pathways. Disturbance of these pathways occurs in MetS. In this kind of milk, insulin might be present in nanometer-sized particles transporting it into the blood. In addition, it may contain insulin-like molecules which have similar interactions with its receptor (14). In all parts of the world where camel lives, its milk is traditionally fermented. Fermentation may augment its health benefits through fermenting probiotic bacteria. The homemade Fermented Camel Milk (FCM) in Turkey, Kazakhstan, and Turkmenistan (15) and by Turkmens in Iran is called "Chal" or "Shubat". In northern Iran, for the first time, a kind of pasteurized FCM similar to Chal has been industrially produced. This product was used in this study due to its pasteurization aspect. It is reported that pasteurization does not affect the chemical composition of camel milk (16).
Limited data exist on the association between fermented dairy intake and MetS. Moreover, there was no published information about the effect of fermented camel milk consumption on MetS or its features in humans. This work as part of a larger study aimed to investigate the effect of FCM on obesity and blood pressure measures of adolescents with MetS.

\section{Methods}

\subsection{Study design and patients}

This double-blind, two-treatment two-period $(2 \times 2)$ crossover and the randomized controlled clinical trial was scientifically and ethically approved (code: 193059) by Isfahan University of Medical Sciences (IUMS) and registered (ID: IRCT201508081202N2) in www.irct.ir. The study participants were adolescents with MetS, which is defined as having at least three of the following criteria according to de Ferranti et al. (17) Fasting Blood Sugar (FBS) modified based on IDF criteria, as follows: 1 . Fasting triglycerides $\geq 1.1 \mathrm{mmol} / \mathrm{L}(100 \mathrm{mg} / \mathrm{dL})$; 2. $\mathrm{HDL}<1.3 \mathrm{mmol} / \mathrm{L}(50 \mathrm{mg} / \mathrm{dL})$, except in boys aged 15 to 19 years, in whom the cut-off point was $<1.2 \mathrm{mmol} / \mathrm{L}$ $(45 \mathrm{mg} / \mathrm{dL}) ; 3$. Fasting glucose $\geq 5.6 \mathrm{mmol} / \mathrm{L}(100 \mathrm{mg} /$ $\mathrm{dL}) ; 4$. Waist Circumference (WC) $>75$ th percentile for age and gender; and 5 . Systolic blood pressure $>90^{\text {th }}$ percentile for gender, age, and height.

Inclusion criteria were being Iranian and 11-18 years old, being diagnosed with MetS or otherwise healthy, lack of using medications or dietary regimens at least one month before the trial, no smoking, no history of allergies to dairy, signing an informed consent by at least one parent and the adolescent participants. Exclusion criteria consisted of the occurrence of any serious illnesses, leaving trial products for more than 3 consecutive or 7 interrupted days, not willing or able to continue study participation.

The sample size was determined based on the statistical power of $80 \%$ and type I error of $5 \%$ for detecting at least a standardized effect size of 1 for Homeostatic Model Assessment Insulin Resistance (HOMA-IR) as the study's main outcome (9). It was finally calculated to be 22 patients. The study participants were consecutively recruited from March 2016 to December 2016 through screening the overweight or obese adolescents referring to the affiliated clinic of Child and Growth Development Research Center (in Amin Hospital, IUMS), and the private practice offices of the study's principal investigators. More details about the methods and procedures of the main study have been presented elsewhere $(18,19)$. 


\subsection{Study procedure}

The biostatistician supervisor, blindly and randomly assigned eligible adolescents (1:1) to either type A or type $B$ dairies at the onset of the first period ( $A B$ sequence or BA sequence). Then, for the second period, the participants switched to alternative treatments. Random allocation list was produced by generating a list of random numbers from a uniform distribution in SPSS and applying block randomization of size 2 in Stata based on age group and gender, i.e. we conducted stratified randomization based on age and gender along with block randomization in each stratum.

After phone calls, those who referred were placed into the two groups based on the randomization list. Informed consents were signed by the study participants. The researchers were aware that the study participants might receive FCM or Diluted Cow Yogurt (DCY); however, we were blinded which of the $A$ and $B$ products is FCM or DCY. The intervention comprised of $250 \mathrm{~mL}$ of type A dairy per day use for 8 weeks in one group and $250 \mathrm{~mL}$ per day of type $B$ dairy product in the other group. After a 4-week washout period (9), the groups crossed and each participant consumed the other type of dairy for another 8 weeks. FCM was the test and DCY was the control product. DCY was produced from cow milk by ordinary yogurt bacteria (Streptococcus thermophilus, Lactobacillus delbrueckii subsp. bulgaricus), then diluted by water and salt to produce DCY. Lactobacilli were used in the production of FCM as well. Dietary constituents of them are presented elsewhere (18-19).

Both products were obtained from one factory, were completely alike in physical appearance and opaque bottling, and only differed in labels as A or B. Both were sour in taste and similar in flavor. The only person who knew the exact content of the bottles was the factory manager. Participants were not close to each other. They were requested to bring back the empty bottles and were encouraged to have a healthy lifestyle. The participants were not on special dietary regimens and only followed the general healthy eating rules. We provided them a pamphlet explaining healthy diet and physical activity habits and requested them to follow those.

\subsection{Measurements}

Blood pressure and anthropometric measurements consisting of height, weight, BMI, BMI z-score, WC, and Hip Circumference $(\mathrm{HC})$ were performed in one week prior to, and the first week after each period (4 measurements for every adolescent). They were measured according to standard protocols in the clinic of Amin Hospital. Weight was measured with least possible clothing by a calibrated scale (QF-2003A; China) to the nearest $0.2 \mathrm{~kg}$ and height, waist and hip were measured by a standard strip meter to the nearest 0.5 centimeters; measurement of barefoot height was done in standing position adjacent to a straight wall. BMI was calculated as weight $(\mathrm{kg})$ divided by height squared $\left(\mathrm{m}^{2}\right)$.

Systolic and diastolic blood pressures were measured twice, at rest and with 10 minutes lasting interval by calibrated sphygmomanometer (Aneroid, Velcro cuff, No.500-V, ALPK2; Japan) covering two-thirds of the adolescent's arm. Mean of two measures was used in the statistical analysis. Immediately before and after each period, the subjects were referred to take some fasting laboratory tests which their results are reported elsewhere $(18,19)$. A standard three-day food record was completed one week prior to each period. Their nutritional data were calculated based on related tables and transformed to participants' intakes by Nutritionist 4 software modified for Persian foods nutrition. A transculturally adapted physical activity scale was completed at the same time.

\subsection{Statistical analyses}

Normality of continuous data was evaluated using the Kolmogorov-Smirnov test and Q-Q plot. Right skewed data were subjected to logarithmic transformation. Continuous data were reported as mean \pm SE or SD and categorical data as frequency (percentage). Intervention, time and carryover effects were evaluated by specific statistical approaches for the analysis of $2 \times 2$ crossover design using $R$ free statistical software (3.3.3) (R: A Language and Environment for Statistical Computing, $R$ Core Team, R Foundation for Statistical Computing, Vienna, Austria, 2017, https://www.R-project.org). SPSS was used for other statistical analyses.

\section{Results}

Overall, 27 eligible adolescents were enrolled in the study. Three of the study participants were excluded from the study. Finally, 24 adolescents completed the crossover trial (58\% girls); with the Mean \pm SD age of $13.77 \pm 1.87$ (age range: $10.45-16.25$ ) years and a body weight range of 42.1-93.4 kg (average: 66.20$)$. More details of the study are presented in Figure 1.

The type A dairy finally was revealed to be FCM and the type B was DCY. Baseline characteristics of participants who completed the study are summarized in 


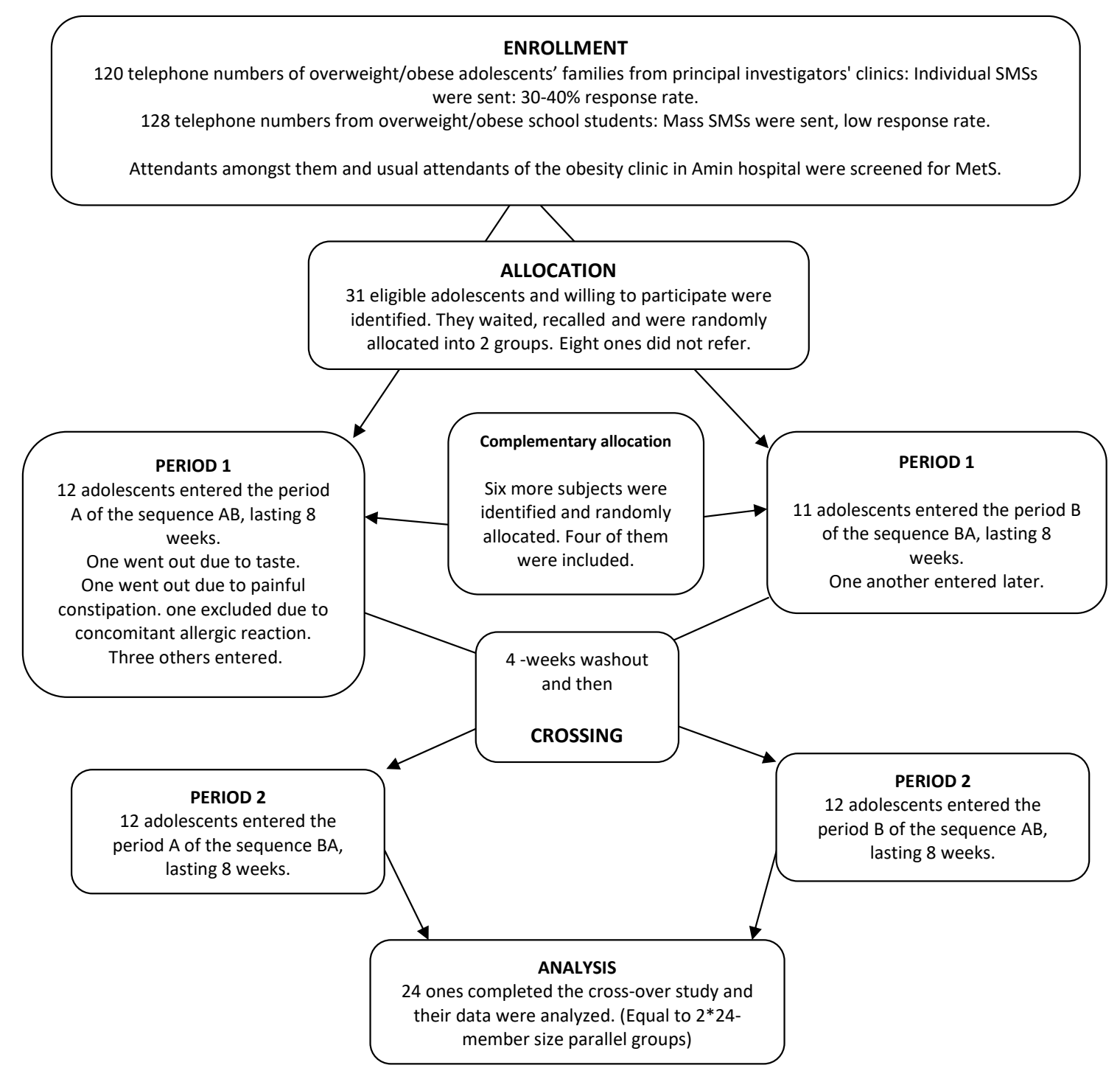

Figure 1. Flowchart of the trial

Journal of Pediatrics Review

Table 1. No significant difference existed between the baseline characteristics of participants of two groups.

As detailed in Table 2, crossover analysis for anthropometric measures suggested that weight, BMI, BMI zscore, WC, HC, and WHR had a nonsignificant increase or slight decrease in the mean scores by FCM consumption in comparison to DCY. Crossover analysis for blood pressure resulted in non-significant mean score reduction in DBP by FCM consumption compared to DCY. Systolic Blood Pressure (SBP) with a mean decrease of -5.52 $\mathrm{mmHg}(95 \% \mathrm{Cl}:-12.82 ; 1.78 ; \mathrm{P}=0.13)$ had a significant carryover effect $(\mathrm{P}=0.040)$. We compared the groups based on the obtained data in the first period; however, we could not find any decreasing effects on SBP.

\section{Discussion}

This trial resulted in beneficial but nonsignificant effects of FCM on the indices of general and abdominal obesity consisting of weight, BMI, BMI z-score, waist circumference, hip circumference, WHR, and blood pressure of adolescents with MetS. This study used a special type of dairy, FCM, which to the best of our knowledge has not been previously studied in clinical trials.

Dairy products have protein-stimulated metabolic effects which differ by their amino acid composition, the rate of absorption, and protein or food texture (20). The incorporation of functional foods and bioactive nutrients can serve as dietary treatment strategies in MetS (21). In relation to obesity measures, the favorable effects of fermented milk on BMI and abdominal adipos- 
Table 1. The baseline characteristics of all study participants in the intervention and control ( $A$ and $B$ ) groups (participants in both periods)

\begin{tabular}{|c|c|c|c|c|}
\hline Baseline Parameter & Treatment & $\begin{array}{l}\text { Total Number of Participants Who } \\
\text { Received Treatments in Both Periods }\end{array}$ & Mean $\pm S D$ & $\mathbf{P}$ \\
\hline Weight, kg & $\begin{array}{l}\text { A } \\
B\end{array}$ & $\begin{array}{l}24 \\
24\end{array}$ & $\begin{array}{l}67.37 \pm 14.72 \\
66.60 \pm 14.86\end{array}$ & 0.92 \\
\hline Height, $\mathrm{cm}$ & $\begin{array}{l}\mathrm{A} \\
\mathrm{B}\end{array}$ & $\begin{array}{l}24 \\
24\end{array}$ & $\begin{array}{c}157.00 \pm 8.92 \\
156.98 \pm 9.54\end{array}$ & 0.99 \\
\hline $\mathrm{BMI}, \mathrm{kg} / \mathrm{m}^{2}$ & $\begin{array}{l}\text { A } \\
\text { B }\end{array}$ & $\begin{array}{l}24 \\
24\end{array}$ & $\begin{array}{l}27.05 \pm 3.98 \\
26.75 \pm 4.09\end{array}$ & 0.83 \\
\hline BMI z-score & $\begin{array}{l}\text { A } \\
\text { B }\end{array}$ & $\begin{array}{l}24 \\
24\end{array}$ & $\begin{array}{l}3.54 \pm 1.85 \\
3.04 \pm 1.88\end{array}$ & 0.79 \\
\hline Waist circumference, $\mathrm{cm}$ & $\begin{array}{l}\mathrm{A} \\
\mathrm{B}\end{array}$ & $\begin{array}{l}24 \\
24\end{array}$ & $\begin{array}{l}89.25 \pm 9.35 \\
89.00 \pm 9.49\end{array}$ & 0.91 \\
\hline Waist-to-height ratio & $\begin{array}{l}\mathrm{A} \\
\mathrm{B}\end{array}$ & $\begin{array}{l}24 \\
24\end{array}$ & $\begin{array}{l}0.567 \pm 0.046 \\
0.567 \pm 0.048\end{array}$ & 1.00 \\
\hline Hip circumference, $\mathrm{cm}$ & $\begin{array}{l}\mathrm{A} \\
\mathrm{B}\end{array}$ & $\begin{array}{l}24 \\
24\end{array}$ & $\begin{array}{c}101.50 \pm 9.73 \\
101.46 \pm 9.33\end{array}$ & 0.99 \\
\hline Systolic blood pressure, $\mathrm{mm} \mathrm{Hg}$ & $\begin{array}{l}\mathrm{A} \\
\mathrm{B}\end{array}$ & $\begin{array}{l}24 \\
24\end{array}$ & $\begin{array}{c}107.69 \pm 12.95 \\
105.13 \pm 9.81\end{array}$ & 0.93 \\
\hline Diastolic blood pressure, $\mathrm{mm} \mathrm{Hg}$ & $\begin{array}{l}\text { A } \\
B\end{array}$ & $\begin{array}{l}24 \\
24\end{array}$ & $\begin{array}{l}67.08 \pm 6.74 \\
66.88 \pm 6.22\end{array}$ & 0.15 \\
\hline Physical activity score & $\begin{array}{l}\text { A } \\
\text { B }\end{array}$ & $\begin{array}{l}24 \\
24\end{array}$ & $\begin{array}{l}2.15 \pm 0.67 \\
2.09 \pm 0.69\end{array}$ & 0.76 \\
\hline Energy intake, Kcal/d & $\begin{array}{l}\text { A } \\
B\end{array}$ & $\begin{array}{l}22 \\
23\end{array}$ & $\begin{array}{c}1667.47 \pm 342.32 \\
1735.54 \pm 487.27\end{array}$ & 0.59 \\
\hline Protein intake, $\mathrm{g} / \mathrm{d}$ & $\begin{array}{l}\mathrm{A} \\
\mathrm{B}\end{array}$ & $\begin{array}{l}22 \\
23\end{array}$ & $\begin{array}{l}78.64 \pm 24.93 \\
78.31 \pm 21.49\end{array}$ & 0.96 \\
\hline Carbohydrate intake, g/d & $\begin{array}{l}\mathrm{A} \\
\mathrm{B}\end{array}$ & $\begin{array}{l}22 \\
23\end{array}$ & $\begin{array}{l}228.69 \pm 49.80 \\
224.81 \pm 61.73\end{array}$ & 0.81 \\
\hline Fat intake, g/d & $\begin{array}{l}\mathrm{A} \\
\mathrm{B}\end{array}$ & $\begin{array}{l}22 \\
23\end{array}$ & $\begin{array}{l}53.87 \pm 21.82 \\
62.70 \pm 33.17\end{array}$ & 0.30 \\
\hline Calcium intake, mg/d & $\begin{array}{l}\mathrm{A} \\
\mathrm{B}\end{array}$ & $\begin{array}{l}22 \\
23\end{array}$ & $\begin{array}{l}1194.18 \pm 347.62 \\
1007.37 \pm 286.32\end{array}$ & 0.05 \\
\hline Vitamin D intake, microg/d & $\begin{array}{l}\text { A } \\
B\end{array}$ & $\begin{array}{l}22 \\
23\end{array}$ & $\begin{array}{l}1.00 \pm 1.15 \\
1.16 \pm 1.40\end{array}$ & 0.67 \\
\hline Total fiber intake, $\mathrm{g} / \mathrm{d}$ & $\begin{array}{l}\mathrm{A} \\
\mathrm{B}\end{array}$ & $\begin{array}{l}22 \\
23\end{array}$ & $\begin{array}{c}17.26 \pm 6.49 \\
19.60 \pm 8.98217\end{array}$ & 0.32 \\
\hline
\end{tabular}

P derived from independent samples t-test. 


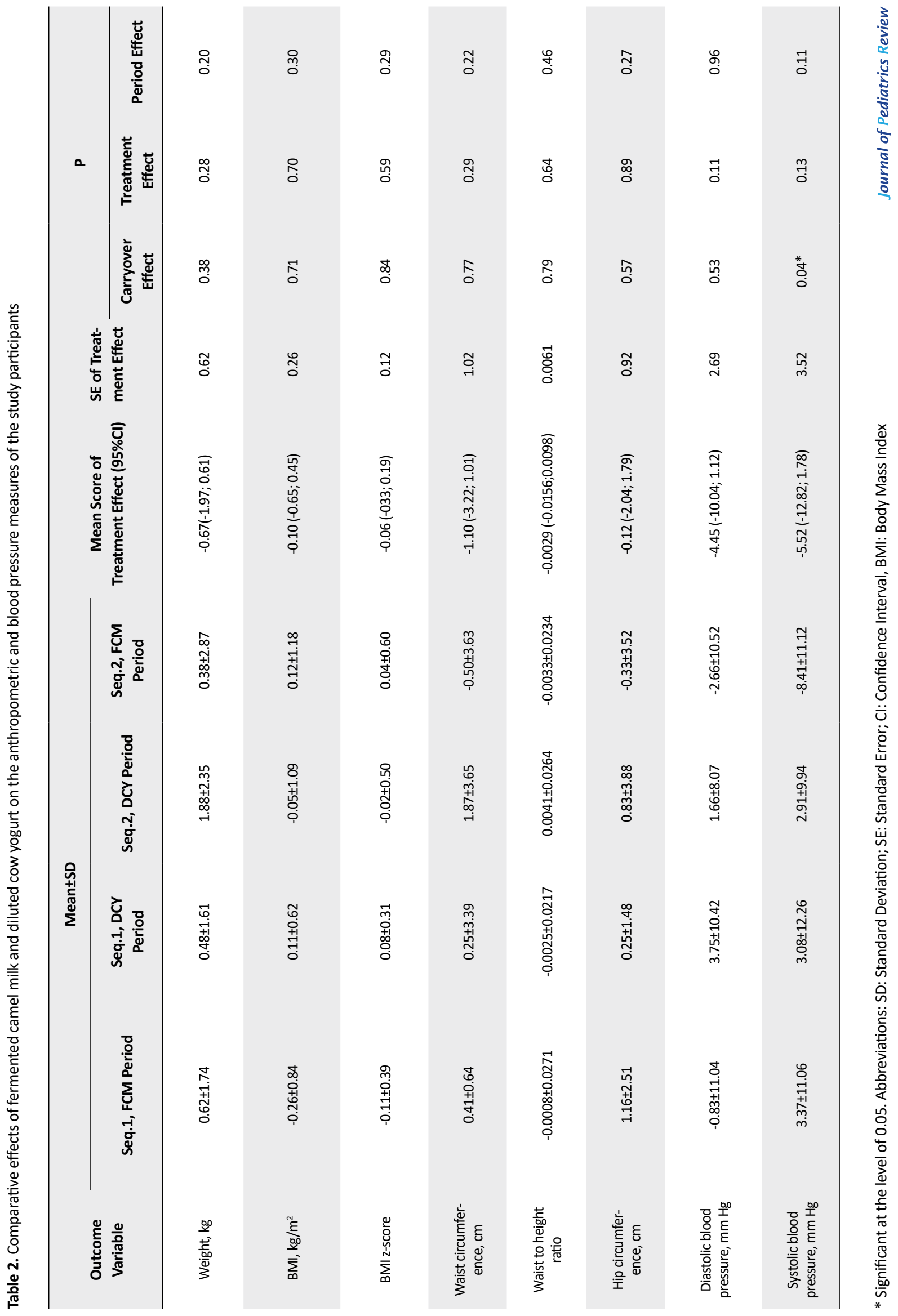


ity, including visceral fat were reported by Kadooka et al. (22) and Takano and colleagues (23).

Agrawal et al. have revealed nonsignificant BMI decrement by camel milk in type 2 diabetes patients (9). Mudgil et al. in vitro study for the first time reported an inhibitory potential of protein hydrolysates from camel milk on diabetes and obesity intermediates (24). Our findings, though nonsignificant, are in accordance with these studies. Moreover, a longitudinal study on adolescents found no association between dairy food consumption and BMI z-score or body fat percentage in adolescents (25). Our findings may have resulted from the special properties of camel milk in comparison to cow milk. Due to the incompliance of adolescents with excess weight with restrictive dietary regimens, this finding is clinically promising.

Our intervention detected a nonsignificant decreasing effect on blood pressure. Usinger et al. meta-analysis revealed a modest overall effect of fermented milk on SBP and no effect on DBP. However, the overall conclusion of authors is that fermented milk does not effect on blood pressure (26). Ejtahed et al. study on camel milk (27), and Hove et al. (28), and Usinger et al. studies on fermented milk demonstrated no significant antihypertensive effects either (29). The small sample size of the study might have resulted in the nonsignificant decrease in blood pressure. Moreover, different types of milk used migh be the reason for the differences between our results and the other two studies. Additionally, Ayyash et al. (30) have demonstrated in vitro antihypertensive activity for FCM. Antihypertensive effect of camel milk and FCM are concluded by Khatoon et al. and Yahya et al. as well $(31,32)$.

In respect of the mechanism, Shori et al. review states that during milk fermentation, an excessive amount of peptides are liberated from milk proteins. Of these are ACE inhibitory and antihypertensive peptides. The concentration of ACE-inhibitory peptides appears to rely on a balance between their formation and subsequent degradation. Thus, fermented milk has potential blood pressure lowering properties (33). Our finding is in line with these studies. Although the finding is not statistically significant, it might be clinically significant due to being achieved without any medications use.

The study has maximal blinding and randomization. Its crossover design makes the cases and controls matched. The financial costs prevented further evaluating the related laboratory parameters. The accessed sample size, amount and the length of consumption have probably impacted on the non-significance of effects. These three were due to the influences of maturity processes on adolescents, seasonal manufacturing difficulties of FCM and the issues related to laboratory kits. The amount and length of consumption were determined based on previous studies with camel milk, products sustainability, sourness and probable consequent weakness of FCM and DCY consumption and adolescents' compliance.

\section{Conclusion}

The beneficial effects of FCM on the anthropometric measures and blood pressure of adolescents with MetS, as preliminary findings of this study, need to be explored in future investigations. Many of the present study findings may be attributed to the properties of camel milk as a special dairy and to its fermented state. Further studies are required to reveal the exact mechanisms of its action and evaluate the clinical impacts of camel milk products.

\section{Ethical Considerations}

\section{Compliance with ethical guidelines}

This double-blind, two-treatment two-period $(2 \times 2)$ crossover and the randomized controlled clinical trial was scientifically and ethically approved (code: 193059) by Isfahan University of Medical Sciences and registered (ID: IRCT201508081202N2) in www.irct.ir.

\section{Funding}

This study was funded as part of a PhD. thesis of Zahra Fallah in Department of Pediatrics, School of Medicine Isfahan University of Medical Sciences, under the grant number of 193059. The relevant charges of the factory which produced dairy products (Fajre-Shahdaneh-yeTabarestan, Sari, Iran) were totally compensated by the research grant.

\section{Authors contributions}

Conceptualizatio: Zahra Fallah; Methodology: Awat Feizi, Zahra Fallah, Roya Kelishadi; Investigation: Zahra Fallah, Roya Kelishadi, Nasim Namazi, Leila Azarbayejani; Statistical supervision and analysis: Awat Feizi; Writing-original draft: Zahra Fallah, Awat Feizi, Nasim Namazi, Leila Azarbayejani; Writing-review \& editing: Roya Kelishadi, Awat Feizi, Zahra Fallah; Final approval and permission to submit: All authors; Funding acquisition: Roya Kelishadi; Resources: Roya Kelishadi, Zah- 
ra Fallah, Awat Feizi; and Supervision: Roya Kelishadi, Awat Feizi.

\section{Conflict of interest}

The authors declared no conflict of interest.

\section{Acknowledgements}

The authors would thank Fajre-Shahdaneh-ye-Tabarestan, Sari, Iran, and especially Mr. Mohammad-Mahdi Zardoost, the factory manager then. Milad Medical Laboratory (Isfahan, Iran) did the laboratory tests and their kind efforts are appreciated.

\section{References}

1. GBD 2013 DALYs and HALE Collaborators. Global, regional, and national Disability-Adjusted Life-Years (DALYs) for 333 diseases and injuries and Healthy Life Expectancy (HALE) for 195 countries and territories, 1990-2016: A systematic analysis for the global burden of disease study 2016 . Lancet. 2017; 390(10100):1260-344. [DOI:10.1016/S01406736(17)32130-X]

2. Collaborators GRF. Global, regional, and national comparative risk assessment of 84 behavioural, environmental and occupational, and metabolic risks or clusters of risks, 1990-2016: A systematic analysis for the global burden of disease study 2016. Lancet. 2017; 390(10100):1345-422. [DOI:10.1016/S0140-6736(17)32366-8]

3. Gore FM, Bloem PJ, Patton GC, Ferguson J, Joseph V, Coffey C, et al. Global burden of disease in young people aged 10-24 years: A systematic analysis. Lancet. 2011; 377(9783):2093102. [DOI:10.1016/S0140-6736(11)60512-6]

4. Tabesh M, Noroozi A, Amini M, Feizi A, Saraf-Bank S, Zare $M$. Association of retinol-binding protein 4 with metabolic syndrome in first-degree relatives of type 2 diabetic patients. Journal of Research in Medical Sciences. 2017; 22:28. [DOI:10.4103/1735-1995.200270] [PMID] [PMCID]

5. Ramic E, Prasko S, Mujanovic OB, Gavran L. Metabolic Syndrome -Theory and Practice. Materia Socio-Medica. 2016; 28(1):713. [DOI:10.5455/msm.2016.28.71-73] [PMID] [PMCID]

6. Akbarzadeh Z, Nourian M, Hovsepian S, Kelishadi R. [Dietary patterns and metabolic syndrome in children and adolescents: A systematic review (Persian)]. Journal of Pediatrics Review. 2018; 6(2):1-13. [DOI:10.5812/jpr.11656]

7. Mansour AA, Nassan MA, Saleh OM, Soliman MM. Protective effect of camel milk as anti-diabetic supplement: biochemical, molecular and immunohistochemical study. African Journal of Traditional, Complementary, and Alternative Medicines. 2017; 14(4):108-19. [DOI:10.21010/ajtcam. v14i4.13] [PMID] [PMCID]
8. Agrawal RP, Jain S, Shah S, Chopra A, Agarwal V. Effect of camel milk on glycemic control and insulin requirement in patients with type 1 diabetes: 2-years randomized controlled trial. European Journal of Clinical Nutrition. 2011; 65(9):1048-52. [DOI:10.1038/ejcn.2011.98] [PMID]

9. Agrawal RP, Sharma P, Gafoorunissa SJ, Ibrahim SA, Shah B, Shukla DK, et al. Effect of camel milk on glucose metabolism in adults with normal glucose tolerance and type 2 diabetes in Raica community: A crossover study. Acta Bio Medica Atenei Parmensis. 2011; 82(3):181-6. [PMID]

10. Meena S, Rajput YS, Pandey AK, Sharma R, Singh R. Camel milk ameliorates hyperglycaemia and oxidative damage in type- 1 diabetic experimental rats. The Journal of Dairy Research. 2016; 83(3):412-9. [DOI:10.1017/ S002202991600042X] [PMID]

11. Korish A. The antidiabetic action of camel milk in experimental type 2 diabetes mellitus: An overview on the changes in incretin hormones, insulin resistance, and inflammatory cytokines. Hormone and Metabolic Research. 2014; 46(6):404-11. [DOI:10.1055/s-0034-1368711] [PMID]

12. Ebaid $\mathrm{H}$. Promotion of immune and glycaemic functions in streptozotocin-induced diabetic rats treated with un-denatured camel milk whey proteins. Nutrition \& Metabolism. 2014; 11:31. [DOI:10.1186/1743-7075-11-31] [PMID] [PMCID]

13. Mirmiran P, Ejtahed HS, Angoorani P, Eslami F, Azizi F. Camel milk has beneficial effects on diabetes mellitus: A systematic review. International Journal of Endocrinology and Metabolism. 2017; 15(2):e42150. [DOI:10.5812/ijem.42150]

14. Malik A, Al-Senaidy A, Skrzypczak-Jankun E, Jankun J. A study of the anti-diabetic agents of camel milk. International Journal of Molecular Medicine. 2012; 30(3):585-92. [DOI:10.3892/ijmm.2012.1051] [PMID]

15. Shori AB. Comparative study of chemical composition, isolation and identification of micro-flora in traditional fermented camel milk products: Gariss, Suusac, and Shubat. Journal of the Saudi Society of Agricultural Sciences. 2012; 11(2):79-88. [DOI:10.1016/j.jssas.2011.12.001]

16. Farah Z. Camel milk properties and products. St. Gallen: Swiss Centre for Development Cooperation in Technology and Management; 1996. [PMCID]

17. de Ferranti SD, Gauvreau K, Ludwig DS, Neufeld EJ, Newburger JW, Rifai N. Prevalence of the metabolic syndrome in American adolescents: Findings from the third national health and nutrition examination survey. Circulation. 2004; 110(16):2494-7. [DOI:10.1161/01.CIR.0000145117.40114. C7] [PMID]

18. Fallah Z, Feizi A, Hashemipour M, Kelishadi R. Positive effect of fermented camel milk on liver enzymes of adolescents with metabolic syndrome: A double-blind, randomized, cross-over trial. Materia Socio Medica. 2018; 30(1):20-5. [DOI:10.5455/msm.2018.30.20-25] [PMID] [PMCID]

19. Fallah Z, Feizi A, Hashemipour M, Kelishadi R. Effect of fermented camel milk on glucose metabolism, insulin resist- 
ance and inflammatory biomarkers of adolescents with metabolic syndrome: A double-blind, randomized, crossover trial. Journal of Research in Medical Sciences. 2018; 23:32. [DOI:10.4103/jrms.JRMS_1191_17] [PMID] [PMCID]

20. Bendtsen LQ, Lorenzen JK, Bendsen NT, Rasmussen C, Astrup A. Effect of dairy proteins on appetite, energy expenditure, body weight, and composition: A review of the evidence from controlled clinical trials. Advances in Nutrition. 2013; 4(4):418-38. [DOI:10.3945/an.113.003723]

21. Andersen CJ, Fernandez ML. Dietary strategies to reduce metabolic syndrome. Reviews in Endocrine \& Metabolic Disorders. 2013; 14(3):241-54. [DOI:10.1007/s11154-0139251-y] [PMID]

22. Kadooka Y, Sato M, Ogawa A, Miyoshi M, Uenishi H, Ogawa $\mathrm{H}$, et al. Effect of lactobacillus gasseri SBT 2055 in fermented milk on abdominal adiposity in adults in a randomised controlled trial. British Journal of Nutrition. 2013; 110(9):1696703. [DOI:10.1017/S0007114513001037] [PMID]

23. Takano Y, Kobayashi T, Kawasaki Y, Akai Y, Ikuyama K, Tsuchida T. Visceral fat-reducing effect of fermented milk containing the probiotic Lactobacillus gasseri SBT2055. Japanese Pharmacology and Therapeutics. 2013; 41(9):895-903.

24. Mudgil P, Kamal H, Yuen GC, Maqsood S. Characterization and identification of novel antidiabetic and antiobesity peptides from camel milk protein hydrolysates. Food Chemistry. 2018; 259:46-54. [DOI:10.1016/j.foodchem.2018.03.082] [PMID]

25. Phillips SM, Bandini LG, Cyr H, Colclough-Douglas S, Naumova $E$, Must A. Dairy food consumption and body weight and fatness studied longitudinally over the adolescent period. International Journal of Obesity and Related Metabolic Disorders. 2003; 27(9):1106-13. [DOI:10.1038/ sj.ijo.0802370] [PMID]

26. Usinger L, Reimer C, Ibsen H. Fermented milk for hypertension. Cochrane Database of Systematic Reviews. 2012 2012(4):CD008118. [DOI:10.1002/14651858.CD008118.pub2]

27. Ejtahed HS, Niasari Naslaji A, Mirmiran P, Zraif Yeganeh $M$, Hedayati M, Azizi F, et al. Effect of camel milk on blood sugar and lipid profile of patients with type 2 diabetes: A pilot clinical trial. International Journal of Endocrinology and Metabolism. 2015; 13(1):e21160. [PMID] [PMCID]

28. Hove KD, Brons C, Faerch K, Lund SS, Rossing P, Vaag A. Effects of 12 weeks of treatment with fermented milk on blood pressure, glucose metabolism and markers of cardiovascular risk in patients with type 2 diabetes: A randomised double-blind placebo-controlled study. European Society of Endocrinology. 2015; 172(1):11-20. [DOI:10.1530/EJE-14-0554]

29. Usinger L, Jensen LT, Flambard B, Linneberg A, Ibsen $H$. The antihypertensive effect of fermented milk in individuals with prehypertension or borderline hypertension. Journal of Human Hypertension. 2010; 24(10):678-83. [DOI:10.1038/jhh.2010.4] [PMID]
30. Ayyash M, Al-Dhaheri AS, Al Mahadin S, Kizhakkayil J, Abushelaibi $A$. In vitro investigation of anticancer, antihypertensive, antidiabetic, and antioxidant activities of camel milk fermented with camel milk probiotic: A comparative study with fermented bovine milk. Journal of Dairy Science. 2018; 101(2):900-11. [DOI:10.3168/jds.2017-13400] [PMID]

31. Khatoon $\mathrm{H}$, Najam R. Bioactive components in camel milk: Their nutritive value and therapeutic application. In: Watson R, Collier RJ, Preedy V, editors. Nutrients in Dairy and their Implications on Health and Disease. Cambridge: Academic Press; 2017.

32. Yahya MA, Alhaj OA, Al-Khalifah AS. Antihypertensive effect of fermented skim camel (Camelus dromedarius) milk on spontaneously hypertensive rats. Nutricion Hospitalaria. 2017; 34(2):416-21. [DOI:10.20960/nh.1163] [PMID]

33. Shori AB, Baba AS. Fermented milk derives bioactive peptides with antihypertensive effects. Integrative Food, Nutrition and Metabolism. 2015; 2(3):178-81. [DOI:10.15761/ IFNM.1000126] 